\title{
Environmentalism and ecologism
}

\section{4}

Environmentalism and ecologism constitute one of the most recent ideological movements. Though the terms are often used interchangeably, it is more useful to regard ecologism as a philosophy that believes in a thorough-going root and branch transformation of society, whereas environmentalism believes that dangers to the environment can be tackled within the existing political, economic and cultural order. We examine here the genesis of the movement in the explosion of concern at the apparent threat to the planet in the 1960s, and its subsequent evolution as an ideological force and political movement. The various elements, spiritual and scientific, which have influenced the 'green' movement are presented and subjected to critical analysis. Finally, we consider whether the movement is little more than a current fad, or whether we are all 'green' now.

\section{POINTS TO CONSIDER}

- Can the origins of the ecological movement be realistically traced back to the eighteenth or nineteenth century?

> How far is ecologism a political ideology and how far a quasi-religious faith?

- How far is the green view of man's place in nature a valid one?

- Are the greens correct to adopt such negative views of industrialism?

> How far is green ideology intellectually coherent and based on empirical evidence?

- Are green politics practical politics? 
After ten thousand years of settled societies, and only two hundred years of substantial industrialisation, human activities and the pollution they generate threaten irreversible changes on an unprecedented scale to the world's climate. (Clive Ponting, A Green History of the World, 1991)

When viewing some of the dumpier parts of the earth, it is hard to imagine that there might be arguments in favour of pollution. And yet there are. By any standard of measurement the majority of people on earth are now richer, healthier, and longer-lived than they have ever been ... These improvements in the human condition came with the industrial revolution, which created most of our pollution.

... The countries that are most industrialised and hence, one would think, most polluted have the best morbidity, mortality and income statistics. National wellbeing might also be said to be a by-product of pollution. (P. J. O'Rourke, All the Trouble in the World, 1994)

What would the world be, once bereft

Of wet and of wildness? Let them be left,

$O$ let them be left, wildness and wet;

Long live the weeds and the wildness yet.

(Gerard Manley Hopkins, Inversnaid, 1881)

Environmentalism and ecologism are two strains of what has come to be labelled the 'green movement' or the 'greens' (with or without a capital 'G'). Though the terms 'environmentalism' and 'ecologism' were once used interchangeably, most people would now discern a distinction between them. Environmentalists believe that green issues, however important they are, can be addressed within the existing political and economic structures. To succeed, this would require wise government, appropriate legislation and the voluntary adoption of environmentally sound practices by consumers. Ecologists deny that this is possible. The environmental crisis is so great, they believe, that only a thoroughgoing reorganisation of the political, social and economic system would achieve a solution. This would necessitate a massive change in human values.

The green movement, like all ideological and political movements, is driven by people with a complex mix of ideas, often in conflict and usually involved in controversy with their fellow greens and with their ideological opponents. This is to be expected of a movement that is so new and is still working out its fundamental beliefs and a political strategy to garner support and win influence and power in the conventional political world. It is not an easy task for a movement that challenges many of the fundamental assumptions of the modern industrialised world.

For most of this chapter we will concentrate on the more ideologically distinct views of ecologism, but the ways in which other movements have been influenced by environmentalism will also be discussed. For convenience we shall use the term 'green' when referring to any position with an ecological slant to it, and 'Green' when referring to a political party. 


\section{The rise of environmentalism and ecologism}

The term 'environmentalism' defines concern for the natural world and its protection from excessive human depredation. It constitutes no clear political or ideological agenda. The term is derived from the Ancient Greek words oikos ('household', 'habitat') and logos ('science', 'argument'). Precursors of ecologism can be found in the writings of Greek and Roman poets and their love of the bucolic life on their country estates (although they might be more properly viewed as, at most, 'environmentalist' in their view of nature). Medieval and Renaissance poets and artists celebrated the natural world and its spiritual values. But it was during the eighteenth and nineteenth centuries that there arose a strong reaction to the world view derived from Judeo-Christian religious and moral values, the mechanistic ideas of Cartesian philosophy and Newtonian physics, and, most of all, the industrial revolution. Rousseau's writings were highly critical of the 'corrupting' nature of 'civilisation' and contrasted the modern world unfavourably with the peaceful, agrarian world of the American 'noble savage'.

Nineteenth-century Romanticism and a love of wild places as displayed in the poems of William Wordsworth and the Lakeland poets were also part of the reaction to industrialism. The twentieth century saw the growth of the 'countryside' as a place of recreation and leisure pursuits, a place for the urbanised to live out Arcadian fantasies (especially if they earned their living in the towns). Perhaps most significant are such critics of industrialisation as William Morris and Leo Tolstoy, both of whom exposed industrialisation as taking the human value, satisfaction and skill out of work, as well as destroying what was beautiful in the natural world. Nor are the origins of ecologism always to be found among the libertarian left - rather embarrassingly for

Romanticism

A style of arts and thought of the late eighteenth century concerned with expressing feeling and emotion. It involved a revolution in thinking about the basic values of art, morals, politics and religion. It sought to create a world view infinitely larger and more varied than the one it set out to supplant.

\section{Arcadia}

A word used to describe an idealised landscape of rural simplicity. Arcadia is something of a fantasy-land of happy, contented peasants enjoying the fruits of their labour, conjured up by those who have never had to earn a living from the land. modern greens. The Nazis, for example, were influenced by some green concerns, such as alternative energy sources and soil conservation.

The experience of most people in the industrial cities of the nineteenth century was one of breaking human ties with nature and the natural world. Britain has the oldest industrial-urban population in the world. Most Britons are now five generations from the land and from working the natural environment. Indeed, for most of the last century the British rural environment has itself been subject to the processes of industrialised agriculture to meet the demand for food and raw materials. 
While environmentalism is manifestly of long standing, the modern ecological movement can be dated from the 1960s and 1970s when a number of books, studies and reports appeared which argued that humanity, even the living world - the biosphere - was under unique threat from a combination of over-population, intensive agricultural methods and chemical pollution. The greatest single threat was the profligacy of the

biosphere

The area of the earth in which life in its many and varied forms exists; the film of life that covers the surface of the earth both on land and in the seas. Environmentalists argue that the biosphere is threatened by modern industrial and farming activities. industrial process itself, a process based on false assumptions. Economic resources (most notably fossil fuels) were not infinite. The external costs of economic development, such as the destruction of the rain forests, the poisoning of the oceans and the rapid extinction of many living species, could not be simply dismissed.

Other anxieties were to follow as the century drew to a close. These included the harmful consequences of the erosion of the ozone layer, global warming, the proliferation of nuclear power generation (and with it nuclear weapons), and the impact of motor vehicles and road building on the environment, human health and wildlife. Spectacular environmental disasters, such as the Seveso dioxin chemical plant disaster in Italy (1976), the Bhopal chemical plant explosion in India (1984) and the Chernobyl nuclear power explosion in the USSR (1986), intensified environmental worries.

The crucial point is that these portents of deep gloom were based on an allegedly scientific analysis of the situation, which gave them an apparently solid intellectual basis and greatly enhanced their persuasiveness. Rachel Carson, in Silent Spring (1962), exposed the damaging impact of pesticides on the human food chain. Paul Ehrlich, in The Population Bomb (1968), raised concerns about rapid population growth and its impact on the environment. Scientific reports, such as the Club of Rome's Limits to Growth (1972), Barbara Ward and Rene Dubos's Only One Earth (1972), and United Nations conferences highlighted the environmental threats. A drumbeat of articles, books and television programmes throughout the 1980s and 1990s produced growing evidence of ozone damage, rising rates of species extinction, resource depletion, and the dangers to the biosphere of new forms of pollution.

The emergence of these concerns coincided neatly with a wide range of spiritual and cultural developments that gave a powerful ethical, almost religious, dimension to the issue. These ranged from criticisms of the dehumanising effects of society and large-scale industrial enterprises, such as Fritz Schumacher's Small is Beautiful: Economics as if People Mattered (1973), to alternative 'New Age' religiosity, and a widespread scepticism, especially among the young, towards the value system of capitalist society. 
These scientific and spiritual dimensions influenced the creation of a political response, which constituted the development of an ideology and the belief that something radical could and should be done about the headlong rush to destruction. This belief emerged from the political upheavals from the 1960s onwards. Political parties with a commitment to an ecologist ideology appeared in the 1980s, and became known as - and even officially called themselves - 'greens'. In the 1990s the collapse of communism, and the apparent intellectual and practical bankruptcy of socialism, have subsequently bolstered the political dimension of the ecological movement. If you still want to be radical, there is nowhere else to go.

The importance of the formation of green political parties lay in their underlying belief that it was necessary and possible to preserve the world. This involved political action. Support for green issues has steadily grown over the last four decades, although it ebbs and flows with the expansion or contraction of the economy. Usually, concern rises with economic growth and full employment and declines when the economy moves into recession and jobs are at risk.

\section{Green is different}

At this juncture it is perhaps useful to point out that ecologism is different from other ideologies in several ways, besides its comparative youth. First, though, a caveat. In practice there is often a marked gap between the policies of parties which profess a particular ideology and the principles of the ideology itself. Differences arise from the exigencies of functioning as a political party in a given constitutional, social and cultural context, such as the simple need to win as many votes as possible. As we shall see later, that certainly applies to Green parties in Britain and continental Europe. Moreover, greens themselves tend to confuse issues by implying that they are somehow beyond ideology: for instance, 'neither right nor left but forward' is the slogan of the German Green Party. This is true in the sense that, unlike other ideologies, ecologism puts the animate and inanimate world centre stage, rather than regarding it simply as a resource for human exploitation. Indeed, some thinkers have attempted to construct complete ethical systems in which humankind is not the central concern. Instead, 'Life' itself is.

One can pursue this theme further. Green political allegiance tends to impose certain lifestyle obligations, ranging from utilising bottle banks for recycling to vegetarianism. Ecologism can thus resemble a religious, rather than political creed. There is nothing new in that. All political movements have strong elements of faith and 'pseudo-religious' beliefs in them.

Both the British and the German Green parties have been racked by conflict between 'dark' (or 'deep') 'greens', who favour the most radical approach, and 
'light' (or 'shallow') 'greens' who are much more moderate, pragmatic and, above all, prepared to operate within the existing systems. Dark greens believe that humans should interfere in nature as little as possible, that all species and not just humans - have moral value (and, potentially, moral values). Most dark greens would encourage direct action against polluters and environmental destroyers, and support a move away from the consumerist, industrialist values of modern society. Light greens think that change must come from within the present system, through regulations, tax changes and slower, more sensitive economic growth.

Underlying these differences is a question of fundamental importance: for whom or what is the environment being preserved? The obvious answer is 'for humankind'; we cannot live on 'spaceship earth' without taking into account the well-being of all non-human passengers. The dark green answer, however, is 'not for the benefit of humans, but for the benefit of all creatures'. If one takes this stance man is dethroned from his position at the centre of all things and drastically new ethical structures must be generated.

\section{Green themes}

We will now explore a number of themes that are fundamental to the ecological perspective:

- human nature and nature;

- green views on politics;

- green economics.

\section{Human nature and nature}

Like all ideologies, ecologism incorporates a view of human nature. Unusually, though, human nature is firmly situated in the context of nature in general. Other ideologies, notably liberalism, tend to present the natural world as simply a backdrop for human activities or, as in Marxism, a resource to be exploited for the fulfilment of human aspirations, aspirations assumed to be unlimited. For ecologists, human beings are merely part of a much wider natural order. This order is characterised by interdependence: the well-being of one living species depending on that of others and, in turn, contributing to the well-being of the whole biosphere.

\section{'Spaceship earth'}

It is imperative that humans individually and as societies live in harmony with the rest of creation and according to principles implicit in the natural order. An analogy is sometimes made with a 'spaceship' - 'spaceship earth' - a beautiful but fragile craft and, crucially, all we have got. This fact, plus the inherent 
limitations on resources in the closed system of the 'spaceship', implies definite limits to human activity, especially limits to material consumption. Moreover, the spaceship and the natural world are useful models for human societies, being based on co-operation, diversity, equality of value, balance and selfregulatory stability. Neither the spaceship nor the natural world would survive without these values.

Alone in space, alone in its life-supporting systems, powered by inconceivable energies, mediating them to us through the most delicate adjustments, wayward, unlikely, unpredictable, but nourishing, enlivening, and enriching in the largest degree - is this not a precious home for all of us earthlings? ${ }^{1}$

\section{Population control}

If spaceship earth is to survive, there must be a reduction in the number of passengers it is expected to carry. Greatly influenced by the ideas of Thomas Malthus, Essay on the Principle of Population (1798), an economist who realised that human population growth would inevitably outstrip food supply and create disaster, ecologists have argued for population control and reduction. The twentieth century experienced massive population growth, reaching over 6 billion by its end. By the middle of the twenty-first century world population may stabilise at 8 to 10 billion. Greens fear there are already too many people and that present levels of material wealth (and pollution) cannot be sustained, let alone universal aspirations to (Western) affluence. Excess population has detrimental consequences for bio-diversity, food supplies, environmental preservation, quality of life and the ability of the ecosystem to sustain life - certainly advanced life. Policies should be designed to encourage smaller families, to reduce world population over the long term to perhaps one billion, the estimated population of the world in 1800 .

Such theories are in conflict with many religious and cultural beliefs. Greens apparently have an up-hill struggle in persuading poor folk to reduce their family size when the logic of their societies is that children are assets to help bring in an income and sustain one in old age. Some greens have cheered China's 'one child' policy and even the compulsory sterilisation that occurred in India under a state of emergency during the 1970s, and have advocated even more authoritarian measures. Other greens, alongside politicians in the developing world, point out that one Westerner uses - and wastes - far more of the earth's resources than many dozens of the poorest people. Some discern racist tinges in concern over population growth in Africa and Asia.

\section{Science, mysticism and nature}

In part, green beliefs are based on a scientific analysis of the natural world, an analysis that is generally accepted within the scientific community and lends 
ecologism much of its legitimacy. However, science is often identified by greens as contributing to the problem by creating the technologies that have driven industrialisation and consumerism. Environmentalists believe that science and technology are major elements in the solution to environmental problems. Many ecologists, however, reject science and believe that only major changes in the religious and moral bases of mankind can restore the world and bring humans into a new balance with nature.

Ecologists' mystical appreciation of the natural world is derived from a number of sources, including Eastern religions. The 'oneness' of the human and natural world (especially in Buddhism); the alleged beliefs and natural lifestyles of 'primitive' peoples; and a (largely imaginary) understanding of pre-civilised and pre-Christian societies of the West are enlisted in the green cause.

The quasi-religious understanding of the Gaia hypothesis and the supposed speech of a nineteenth-century American, Chief Seattle, provide an illustration of this strand of green thinking.

The conjunction of scientific theory with a quasi-religious perception of the biosphere is most clearly seen in the 'Gaia hypothesis' of James Lovelock, in Gaia: A New Look at Life on Earth (1979) and The Ages of Gaia: A Biography of Our Living Earth (1989). Put simply, Lovelock argued that the earth was kept habitable for living things by the interaction of innumerable biological systems. Life itself made life possible by a built-in, self-correcting mechanism which automatically took account of changes in the environment and made appropriate adjustments. Thus, although the temperature of the earth has varied considerably over time, the atmosphere has been kept breathable by compensating processes among living creatures.

This apparently objective, scientific description, which has been widely accepted, was translated into a powerful ideological underpinning of green politics by the cultural resonances created by the fact that 'Gaia' was a Greek goddess, 'Mother Earth'. The Gaia thesis was interpreted by some as implying that all life on earth constituted a sort of single living organism, possibly endowed with consciousness and will. It also claimed that the present economic, political and social system was wrecking the subtle interactions that preserved life on planet earth, with potentially catastrophic consequences.

Although actually a forgery, Chief Seattle's speech neatly summarises the ecologists' attitude to the modern world, on which has been conferred the imprimatur of Rousseau's 'noble savage':

If we do not own the freshness of the air and the sparkle of the water, how can you buy them?

We are part of the Earth, and it is part of us. The rocky crests, the juices of the meadows, the body heat of the pony, and man - all belong to the same family. 
The shining water that moves in the streams is not just water, but the blood of our ancestors. If we sell you land, you must teach your children that it is sacred that each ghostly reflection in the clear water of the lakes tells of memories in the lives of my people. The water's murmur is the voice of my father's father. ${ }^{2}$

Such a perception is, of course, in marked contrast to the idea of the natural world and man's relationship to it, as presented in the Judeo-Christian tradition in Genesis. Here God's creation is inherently good but it is emphatically placed under the authority of Man. Indeed, man dominates the rest of creation:

... God said unto man, Be fruitful and multiply, and replenish the Earth and subdue it: and have dominion over the fish of the sea and over the fowl of the air and over every living thing that moveth upon the Earth. ${ }^{3}$

In contrast to humankind's 'domination', modern Christian thinking has redefined man's role as 'steward' over nature, with authority counter-balanced by responsibility for its proper use. Nature is the creation of God and should be treated with respect as His handiwork.

The Christian perception jars with the scientific view of the universe which emerged in the seventeenth century, and which subsequently underpinned the 'Enlightenment' of the eighteenth century. Here the assumption was that the universe could be rationally understood and manipulated to human advantage by breaking it down into its component parts, rather like a machine, to 'see how it worked'. The ecological perspective emphasises a holistic understanding in which the whole is not simply the sum of its parts but transcends them in a developing system, of which mankind is but a part.

It is evident, then, that there is a tension within ecologism, between its 'scientific' and its 'mystical' bases, which has never been wholly resolved.

Critics have denounced as improper the greens' inclination to extract eternal moral principles from scientific studies. For example, although humans are said to be simply part of nature, even the most rigorous advocates of this position imply that humans are somehow outside the system as well. Humans have, uniquely, a moral responsibility to proceed in particular ways, but the question arises why shouldn't humans simply exploit the environment like any other animal? If human actions destroy a species, so what? Millions of species have been eliminated throughout the history of the planet, which would get along well enough without humans, as it did for aeons before humans evolved. Nor is it evident that there is a moral imperative to preserve life on earth; it might be prudent to do so for humankind's survival, but that is not the same thing.

\section{Green views on politics}

It is not easy to fit green political views into the conventional left-right spectrum, nor is it evident that green ideology can be subsumed under the 
general headings of liberal, conservative and socialist. Greens tend to be rather proud of this exclusivity, though in fact most subscribe to the liberal-democratic ideal of much of the Western world. (Eastern religions and primitive tribes seem to be little esteemed as useful models in this regard.) The other major political movements and ideologies all, in the view of greens, tend to assume industrialisation and the consumer society to be a 'good' thing. All believe politics to be heavily involved in the creation of conditions for economic growth, at whatever cost to the planet and its other inhabitants. Traditional ideologies remain overwhelmingly 'human-centric', or anthropocentric, in their beliefs and policies, a bias that green politics sets out to change.

However, this position is not obviously derived from green theories of nature. Indeed, one could argue that conservative thought, with its emphasis on links across the generations, its cautious approach to technological quick-fixes, its precautionary attitude to change, and the value it accords to the agricultural sector, natural harmony and awe in the face of the universe, is closely related to ecologism. More alarmingly, it might be argued that the full implementation of a green agenda would be possible only under a highly authoritarian political system. So far, greens have had only modest success in persuading the masses that they should voluntarily reduce their standard of living. Besides, proposals for reducing population size evoke disturbing comparisons with forced sterilisation in India, the 'one child' policy in China and even eugenics and 'ethnic cleansing'.

There is some sense in which 'democracy' as an ideal can be generated from basic green principles. All living beings can be regarded as 'stakeholders' in the health of the planet. For many greens, this

eugenics

The 'science' of selective breeding by promoting the reproduction of 'desirable humans' and preventing the creation of the 'less desirable'. Eugenics was widely supported by people of all political persuasions, left and right, prior to the Second World War and Nazi eugenics which discredited its precepts. has important implications for the treatment of animals. Greens also champion a very inclusive concept of democracy which includes generations yet unborn who are also 'stakeholders' in the well-being of the planet. Furthermore, nature itself appears to show the value of harmony in diversity - a model therefore for tolerance and a pluralistic society.

Critics have pointed out that 'nature' is a very ambiguous guide for the reconstruction of human society. Nature contains many models, some resembling the most mechanical of totalitarianisms, others a 'Hobbesian' 'war of all against all'. Natural selection, for example, is, as Charles Darwin discovered, a major engine of biological evolution. However, Social Darwinism, an attempt to apply evolutionary ideas to human society, was an important underpinning of racism, fascism, eugenics and mass extermination of assorted people defined as 'sub-human' - hardly a model of natural balance, let alone a basis for human morality. 
As a new ideology, ecologism is still vague about how to move from this wasteful society to a green one. In that sense it is like nineteenth-century Marxism or late eighteenth-century liberalism in presenting a strong critical analysis of society but a weak theory of transformation to another society. This is certainly an area that has to be addressed by green politicians if they wish to make headway in electoral politics.

\section{Green economics}

The starting point of green economics is a critique of the all-pervasive system of 'industrialisation', which constitutes a sort of 'super-ideology', of greater significance than whether society is organised on free-market capitalist or state socialist principles.

\section{Industrialism}

This applies to more than the factory system, more than capitalism, even more than what would be regarded as 'conventional' economics. The main features have been succinctly itemised by Ian Adams:

- a devotion to economic growth and industrial expansion and continuous technical innovation;

- a belief in the overriding importance of satisfying people's material needs;

- large-scale centralised bureaucratic control;

- scientific rationality being the only kind of reasoning that matters;

- large scale units - in industry, administration, etc - are most efficient;

- a predominance of patriarchy and an emphasis on 'masculine' values of competition, aggression and assertiveness;

- an anthropocentric view that sees the earth and all that lives on it as simply there to be exploited for any human purpose;

- a hierarchical social structure where power and wealth is concentrated at the top;

- economic considerations predominate in society and moral, social and artistic values are of lesser importance. ${ }^{4}$

From the green perspective, a society built around the above value system is utterly pernicious. It not only debases human beliefs, it also squanders irreplaceable physical and biological resources and degrades the environment, ultimately to the point of ecological collapse. Nor does such a system provide for genuine human needs: material and spiritual poverty are everywhere apparent, even in the so-called 'developed' world.

Though this system is powerfully entrenched it is based on several demonstrable fallacies. First it assumes, against all reason, that the resources of the earth are infinite, as is its capacity to absorb the detritus of rampant consumerism. Furthermore, against all evidence, the general method of measuring well-being, especially in terms of Gross National Product (GNP), is utterly inadequate and misleading, mostly for what it leaves out of the reckoning. GNP does not measure 'externalities', for example, such as the costs 
to the community of atmospheric pollution, noise, accidents, stress, and so on caused by the constant increase in motor transport. Nor does it measure the distribution of 'wealth' so produced. Even more seriously, the future viability of the economic developments it purports to measure is ignored. Whole swathes of the 'real' economy, such as goods and services provided by informal family and community systems (of crucial significance in any society, but especially in the Third World) are dismissed as insignificant because they are not measurable in monetary terms.

\section{Anti-materialism}

The modern economic system has created vast material wealth, but has done little to increase the sum of human happiness over the last few decades. Material comfort in itself cannot significantly improve the quality of life once most basic material needs have been met (as they have been in the West). Environmentalism, along with justice and equality, is an issue that becomes more important in what many greens call 'post-materialist societies' where quality of life rather than the quantity of material goods becomes increasingly meaningful.

The problem is that most people on earth are poor. They struggle to get the basics of life, let alone comfort. Economic development has progressively dislocated their contact with the natural world but has not established new foundations of social harmony. Greens believe these problems can be solved by the better distribution of existing wealth rather than by greater production. Many in the developing world regard this view as essentially a Western indulgence, even a new form of Western imperialism - 'ecological imperialism' - to keep them subservient.

There are growing numbers of ecologists who realise that there must be close links between environmental programmes and developmental programmes if humans and nature are to have the natural ecological balance restored.

\section{Growth}

Above all, the industrialised system is based on the principle of 'growth'. Greens argue that this growth can and should be halted, or at the very least, dramatically reduced. This would involve a range of radical measures, among them a redefinition of the concept of 'work'. The term 'work' should no longer be confined to paid employment, but should include just about any activity with a beneficial (according to green criteria) outcome. Growing one's own vegetables, helping elderly neighbours, playing the guitar or teaching one's own children at home could all be included. One of the practical consequences is the notion of a guaranteed basic income, in which all citizens would receive as of right a minimum income whether they 'worked' in the conventional sense or not. 
For greens, economic activity should satisfy need, rather than greed. Moreover, it should be so organised as to provide for the social and emotional needs of producers and consumers. To achieve this, greens favour small-scale and co-operative enterprises.

\section{Sustainability}

The application of green criteria to the economy in general would also focus on reducing the consumption of energy and non-renewable resources with the goal of establishing a sustainable system. Greens declare interest in such energy sources as solar, wind, wave and geo-thermal power, rather than nonrenewable fossil fuels like coal or oil, or potentially highly dangerous and costly nuclear power. Greens are also inclined to favour, as part of this 'sustainable' system, reducing trade (so often rigged against the interests of the poor) and encouraging localised production (so as to reduce the drastic environmental costs of transport). New social and political values built around the reduction of pollution and consumption and a more just distribution of wealth within and between societies will be required.

Attractive though this might sound, 'sustainability' is nowhere very clearly defined. Does it mean modest and strictly directed growth, no growth at all, or a reduction in growth?

In fact, green economics poses a number of serious problems, which will be examined further under a critique of the ecologist position.

\section{Critique of the ecologist position}

At first sight ecologism is a persuasive blend of incontrovertible scientific evidence, ethical purity, spiritual insight and humane sensibility. It has an immediate appeal to many, especially the young. Moreover, a green political position implies an almost religious commitment to a lifestyle consonant with its principles. Furthermore, although Green political parties, with an agenda avowedly based on these principles, seem to make as many compromises with mundane reality as any other ideological movement, green thinking has percolated into all the mainstream parties and movements.

Nonetheless, the green position is open to challenge in several key areas. These are:

- Intellectual incoherence;

- scientific implausibility;

- practical difficulties. 


\section{Intellectual incoherence}

Critics have not been slow to point to some fundamental weaknesses. An obvious difficulty is the green argument that because nature exhibits certain features of inter-species co-operation which maintains the biosphere indefinitely, human beings should act in harmony with this fact. This is strikingly evident in the way greens tend to interpret Lovelock's Gaia theory. Philosophers, however, sternly reject the notion that one can make such an ethical link, a logical leap from what is to what ought to be.

Greens are not always consistent about how they understand man's position vis$\grave{a}$-vis the rest of nature. Sometimes it is implied that mankind is simply a part of nature, with no claims to superiority or special treatment, in which case mankind has no more obligations to nature than a slug has to a cabbage leaf. Sometimes, though, they rather shamefacedly admit humans have unique awareness and moral responsibility - mankind is in nature, but not wholly of it.

This confusion is related to another question. Are greens bio-centric or anthropocentric? In other words, is the environment to be preserved for its own sake and its own values, or simply because it suits humanity and human values? For example, it is often argued that the enormous diversity of species in the rain forests should be nurtured because of their possible medicinal value, or that wilderness should be preserved for aesthetic reasons. Deep or dark greens often specifically reject such human-centred values. To them, nature has its own values independent of human concerns.

Again, a number of highly contentious issues lurk along the borderlands of the green world view. Many greens espouse the cause of animal rights, in itself contentious, because such ethical positions appear to be in harmony with the broader green outlook, which might suggest that mosquitoes and flu viruses have as much right to live as humans. But the full interpretation of animal rights could be electorally unpopular; and, even though animal species are in ferocious competition for resources, the concession of full citizenship rights to disease and vermin would amount to mass human suicide. Some fringe groups advocate just that. Critics have been quick to point out an eccentric, even downright crank, element in some green organisations that, for all their claims of scientific probity, give houseroom to 'alternative' medicine, 'pagan' mysticism and general irrationalism.

This brings us to a central conflict within the green outlook, which is its attitude to reason and rationality. Although greens claim to uphold a uniquely science-based ideology, they harbour a deep and abiding suspicion of the scientific tradition and its rational and mechanistic understanding of the universe as a universe that can be analysed and understood rather than mystically apprehended. 
Hard-nosed critics argue that myth, rather than science, dominates the whole green outlook, and the myth in question is the most potent one of all, that of the 'Fall of Man'. This myth presents itself in manifold guises. Sometimes it is suggested that prehistoric man lived in blissful harmony with nature and that all went awry with the invention of agriculture. Sometimes the fall is postponed to the emergence of modern science during the seventeenth century; sometimes the Enlightenment is to blame. But generally the villain is held to be the industrial revolution of the late eighteenth century and after.

\section{Scientific implausibility}

Green writers in the 1960s and 1970s made much of scientific evidence that forecast impending doom. Predictions were made, and given quite detailed statistical support, that raw materials and fuel resources were running out. This would lead to price rises, economic turmoil and ultimately the collapse of the whole economic system. Similarly, population growth would outstrip food production, causing calamitous famines. Pollution would render the atmosphere unbreathable. All these apocalyptic disasters were confidently forecast to occur by the year 2000 at the latest. But they didn't. As a result, critics have dismissed the green outlook as a modern version of the 'end of the world' terrors which have gripped the West at various times over the last millennium.

Of course, in a real sense, all things will come to an end, but this is no basis for a serious political philosophy. In fact, the world has abundant resources. The known reserves of fossil fuels and most metals have risen since the doomladed predictions of the early 1970s. Indeed, the price of most raw materials has tended to decline over the long term as new sources become available. Oil price rises in the 1970s, for example, had much to do with Middle Eastern politics, and the existence of a strong oil-producing cartel, but little to do with the availability of a fossil fuel supply. The high price encouraged fuel conservation and the search for new, more secure deposits of oil in Alaska and the North Sea. Technology has reduced the need for copper in telecommunications and electricity supplies. Most manufactured goods require fewer raw materials in their construction than previously.

Food production has continued to outstrip population growth, reducing the incidence of famine among the world's poor. Malthusian predictions appear to have been confounded (though not, perhaps, proved wrong for all time) as science and technology have dramatically improved the yield of most crops.

Deforestation and diminishing bio-diversity are concerns, but they do not constitute the disaster that most greens would claim. Greens have a record of exaggerating the scale of the crisis, using sloppy scientific methodology, manipulating statistics and making downright dishonest use of many scientific reports to create a false impression of environmental disaster. Indeed, whatever claims 
they make of holding the moral high ground, greens are yet another body of self-interested pressure groups seeking special treatment by government.

Of course there are difficulties, but these can be managed by wise government decisions. The free market can help reduce wasteful consumption of irreplaceable resources, as is the case with oil, and stimulate new pollutionreducing technologies. Alternative energy sources will be developed when the time and prices indicate.

Green preoccupation with planet earth may be parochial; there are effectively unlimited resources of energy and raw materials in outer space which humans will eventually access. The overcoming of adversity by intelligence and ingenuity is the story of human history. Scare stories have always abounded. There was once a fear that the scarcity of oak trees for shipbuilding would render Britain defenceless at sea. Similarly, a shortage of charcoal was supposed to lead to the end of the iron industry in the eighteenth century, except that coal came along as a viable alternative.

Critics regard much green concern about the environment as reactionary. To greens the past is better than the present or any likely future. Greens lack a serious understanding of human history and the social, technological and scientific improvements that have created healthier, wealthier and, in some ways, environmentally more friendly societies. Third World poverty and early death are not, critics point out, very green. Primitive people do not have some superior wisdom, only a shorter life expectancy. Pre-industrial societies also reduce bio-diversity by poor environmental management. (Easter Island is a fine example of 'primitive wisdom' to be avoided.) Much modern environmental degradation, so the anti-greens

Easter Island

An isolated Pacific Ocean island which when visited by Europeans in the eighteenth century appeared to have reached a high level of civilisation that subsequently collapsed. Recent studies suggest this was a

consequence of poor

husbanding of the island's resources. argue, arises from the desperation of poor people to keep themselves and their families alive. Much Western green thinking can be seen as the indulgence of the scientifically illiterate and the comfortably off.

\section{Practical difficulties}

A 'common-sense' view of the green version of society is that it is impractical and utopian. It is all very well to urge the abolition of capitalism and its replacement by 'something nice', but more details are urgently required. Green supporters are often criticised for being typically Western, white, middle-class people with no direct experience of industry or business - teachers, lecturers and the like. Almost by definition these are impractical people, dreamers with little understanding that a green society is a luxury that the poor, especially in the Third World, simply cannot afford. 
Such criticism is not wholly fair. Greens can argue, with some justification, that theirs is a relatively new and dramatically different ideology that is exploring as yet largely uncharted waters.

More serious is the accusation that greens simply have no strategy for moving on from where we are now to where greens want us to be. Sometimes it appears that simply appealing to reason and evidence will in itself transform society. Sometimes the adoption of green lifestyles, ranging from vegetarianism and cycling to various forms of communal living, is presented as the road forward.

There seems little awareness that immensely powerful structures, interest groups and value systems have created the present order, and will be fiercely resistant to any attempts to change it. Moreover, any transformation is likely to be, in the short run and probably in the long run, highly distasteful to large numbers of people. Greens are rather deficient in revolutionary theory, and, unlike Marxists, do not pinpoint any particular social groups who will develop into engines of social change. The assumption that 'everyone' or 'all living things' will be the beneficiaries and thus the instruments of change leaves greens wide open to accusations of naivety and living in a fantasy-world, particularly from the more tough-minded political left who see them as distracting attention from the class struggle.

Green political parties, certainly in the West (and ecologism is very distinctly an ideology of the West), operate within the liberal-democratic political system, but so far not very successfully. Indeed, deep greens tend to regard democratic politics as a form of collaboration with the system that, far from being part of the solution, is in fact part of the problem. Meanwhile, conventional political parties appropriate just enough of the green analysis to give a 'greenish' tinge to some of their own policies, thus neutralising the more radical demands of the movement. The electorate is, in effect, inoculated against a genuine green revolution by mild doses of environmentalism.

However, the deep green programme is no more effective. Demonstrations and media stunts get some publicity but do not drastically challenge the existing order. Some deep greens have sought to remedy this deficiency by constructing some sort of coalition among those most adversely affected by the present arrangements - the unemployed, the marginalised, hill farmers for instance - but with little success. It is uncertain whether such groups are particularly politically aware or open to green persuasion. In fact, most groups appear anxious to get a foothold in the world as it is, rather than to transform it into something different, even if it is 'something nicer'.

\section{The greening of politics}

Many European countries have green political parties. Some, notably in Germany, where Green Party politicians have served in coalition governments, 
have enjoyed modest success. In Britain the Green Party (formed in 1985 out of the Ecology Party, which was founded in 1975) has been far less successful if measured in the conventional terms of votes, elected representatives and levels of opinion-poll support. Votes peaked in the 1989 European Parliament elections but declined rapidly in subsequent Westminster elections, although greens have won a few council seats in local government and the occasional Euro-Parliament seat (on the basis of very low voter turnouts).

Although this might appear to suggest that ecologism is a fringe movement, such an inference would be mistaken. Ecologist, or at least environmental influence, has spread far beyond the Green Party to become a significant feature in mainstream politics. All political parties and movements are anxious to advertise their green credentials.

\section{Conservative environmentalism}

An important element in conservatism is 'conservation' and slow, incremental change in society. Conservatives stress the importance of the generational links between those who have gone before, those who are alive today, and those yet to be born. Conservatism is often linked to anti-industrialisation, anti-urbanism and pro-hunting, the countryside and hunting being vital elements in environmental protection. Environmentalism is very much a countryside and small town or 'historic' city concern. Care about the urban environment tends to centre on the preservation of ancient buildings and townscapes. Somehow, Bath seems more worthy of preservation than Manchester, even though both are Roman towns and both are of considerable 'historical' importance.

\section{Socialist environmentalism}

Socialists argue that capitalism exploits both humans and the natural world. Environmental objectives will be met only by a move towards a post-capitalist society. Many Marxists look on environmentalism as a diversion from the class struggle, while some socialists see it as even more important than the class struggle. Environmental socialists think that class struggle unjustifiably postpones the need to reform society along environmental lines. Planning, tax, regulations and other reforms are needed now to encourage a green lifestyle, including recycling, greater use of public transport and energy efficiency.

\section{Liberal environmentalism}

Liberals argue that the 'market' can help solve most environmental problems. The key issue is that 'public goods', such as fresh air, fish and water, an aesthetically pleasing environment and wild animal species, are 'free'. There is an incentive for people to use up a declining free resource before it is gone. If, however, one places a price on everything in the natural world then the 
market will ensure that valued goods, such as animals, plants, air and water, will survive. The failure of the market adequately to protect the environment derives from interference by government regulations - which distort markets - and from the lack of value placed on the environment by people and businesses. Indeed, the latter exploit the environment with the polluting and damaging side effects of their activities (known as externalities) and leave society to clean up, thus keeping their own costs down. Create a properly functioning market, where people carry the full costs of their activities, and you produce a better way of protecting the environment.

\section{Feminist environmentalism}

This term applies to the belief that a link exists between the male oppression of women and male oppression of Mother Earth as a consequence of male power and male ideologies of domination of the human and natural world. Women have a special role in green politics because of their crucial role as mothers and carers.

\section{Fascist environmentalism}

Environmental concerns are seen as important elements in fascist movements. Earth, forests and mountains are of special significance to the 'soul' of a nation or race. Both Italian Fascism and German Nazism invoked rural and peasant values as the backbone of their movements, even though their militarism involved an expansion of industrialisation to provide the materiel for war. In recent years the French National Front and the British National Party have also sought to stress their green credentials as another way of garnering support from elements of the electorate who are disillusioned at the failures of mainstream parties to treat green issues with great urgency.

\section{Anarchist environmentalism}

Nature left to its own devices exhibits a degree of self-government, harmony, balance and diversity - 'anarchy' - attractive to anarchists, who believe the world's problems spring mainly from formal structures of government. Small communities and self-sufficiency are the goals of this element in the environmental movement.

Several other social and political movements are highly consonant with green attitudes, such as animal rights, vegetarianism, nature conservation and even folk music, canal restoration and real ale.

Radical green politics may be on the wane. In part this is because of insoluble contradictions within the movement. For example, if 'traditional' parties and governments do adopt and implement some effective green proposals, the need 
for revolutionary change is reduced. Again, some green policies are, however much this is denied, essentially technological fixes - such as the development of wind and tidal power, and the introduction of the catalytic converter for motor car exhaust fumes. These, if they work (or at least appear to be working), undermine the deep green case for root and branch social revolution.

However, the evidence still mounts that there are major problems. Global warming and radical climate change continue to be proved by scientific and personal observation of the weather. Reports increasingly identify the scale of the problem. The 2002 Environmental Sustainability Index, for example, placed the UK ninety-eighth out of 142 countries, noting its poor record on reducing air pollution, protecting habitats and reducing greenhouse gases. The UK has one of the worst records for reducing household waste and increasing recycling.

Whether in fact the shift in global consciousness in a green direction leads to a total political change remains to be seen. As things stand, the jury is out. At most it appears to be painfully slow, while the environmental challenges appear to grow. If change does occur it may well be by means outside the conventional constitutional or even revolutionary political traditions by an as yet unidentified process.

\section{Summary}

As ideologies go, environmentalism and ecologism are very recent creations. Environmentalism has come to mean a concern with threats to the environment, threats which can be effectively dealt with within the status quo, while ecologism radically challenges the entire economic and social structure and even proposes a new value system and morality. Both are traceable to a reaction to the Enlightenment, Newtonian physics and industrialisation, but the concerns grew with a widespread realisation in the 1960s that economic expansion and the social structure and value system underlying it could not go on indefinitely without making the planet unfit for life. Greens therefore proposed alternatives ranging from technological solutions to a reordered society and a new value system. Attractive though green ideas appear, they have been attacked as unscientific, impractical and even immoral. Politically the greens have received little electoral support, especially in Britain, but green assumptions and values are increasingly becoming part of the wider political culture. 


\section{REFERENCES AND FURTHER READING}

1 B. Ward and R. Dubos, Only One Earth (André Deutsch, 1972).

2 Chief Seattle, supposedly spoken by him in 1854.

3 Genesis 1:28.

4 I. Adams, Ideology and Politics in Britain Today (Manchester University Press, 1998), p. 177.

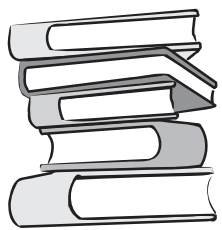

Adams, I. Ideology and Politics in Britain Today (Manchester University Press, 1998).

Bramwell, A. Ecology in the 20th Century: A History (Yale University Press, 1989).

Connelly, J. and Norris, P. 'Making Green Policy: A Guide to the Politics of the Environment', Talking Politics, 4:2 (1991/2), pp. 96-100.

Dobson, A. The Green Reader (Andre Deutsch, 1991).

Dobson, A. Green Political Thought: An Introduction (Routledge, 1992).

Dobson, A. 'Ecologism', in R. Eatwell and A. Wright (eds.) Contemporary Political Ideologies (Pinter, 1993), pp. 216-38.

Goodwin, B. 'Green Ideologies', in B. Goodwin, Using Political Ideas (John Wiley and Sons, 2001), pp. 223-48.

Heywood, A. 'Ecologism', in A. Heywood, Political Ideologies: An Introduction (Macmillan, 1998), pp. 264-90.

Kenny, M. 'Ecologism', in R. Eccleshall et al., Political Ideologies: An Introduction

(Routledge, 1996), pp. 218-51.

McCormick, J. 'Environmental Politics', in Patrick Dunleavy et al., Developments in

British Politics 4 (Macmillan, 1990), pp. 267-84.

Myers, N. (ed.) The Gaia Book of Planet Management (Pan, 1985).

O'Rourke, P. J. All the Trouble in the World (Picador, 1994).

Ponting, C. A Green History of the World (Sinclair-Stevenson, 1991).

Porritt, J. Seeing Green: The Politics of Ecology Explained (Blackwell, 1984).

Vincent, A. 'Ecologism', in A. Vincent, Modern Political Ideologies (Blackwell, 1996), pp. 208-37.

Ward, H. 'Environmental Politics and Policy', in Patrick Dunleavy et al., Developments in

British Politics 3 (Macmillan, 1990), pp. 221-45.

\section{SAMPLE QUESTIONS}

1 On what grounds do ecologists attack industrialism?

2 Is the green analysis simply nostalgia for a non-existent past?

3 How fundamental are the differences between environmentalists and ecologists?

4 How scientific is the ecologist position?

5 Is it true to say 'we are all green now'?

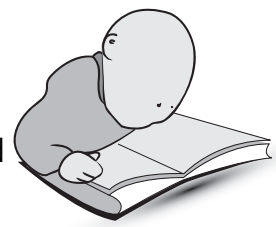

